\title{
Prevalence of thyroid disorders among children with Down syndrome seen in the out-patient clinics of the Philippine general hospital
}

\author{
Lalaine Audrey Matitu-Untalan*, Sylvia C Estrada \\ From 8th APPES Biennial Scientific Meeting \\ Darwin, Australia. 29 October - 1 November 2014
}

\section{Background}

Thyroid disorders are noted to occur in $28-40 \%$ of children with Down syndrome [1]. Hypothyroidism has a subtle presentation and can be particularly challenging to detect in patients with intellectual disabilities and communication and language impairments [2]. Regular screening and early diagnosis of thyroid disorders, particularly hypothyroidism, is essential for early intervention.

\section{Objective}

To determine the prevalence of thyroid disorders among children with Down Syndrome (DS) seen in the outpatient clinics of the Philippine General Hospital from January 2007 to December 2011.

\section{Secondary objectives}

To classify the thyroid disorders present; to describe the clinical profiles and genotype of the children with Down syndrome.

\section{Methodology}

A Retrospective chart review of all patients with Down syndrome seen in the Out-patient Clinics of the Philippine General Hospital from January 2007 to December 2011.

\section{Results}

Eighty-nine patients were included, $60 \%$ males and $40 \%$ females .Fifty-six percent had thyroid disorders. Of these, eighty percent had subclinical hypothyroidism, $12 \%$ had overt hypothyroidism, while $8 \%$ had hyperthyroidism. The mean age for the diagnosis of thyroid disorder was $3.33( \pm 0.52)$ years old. The mean age on initial consult was $2.38( \pm 3.14)$ years. The mean age of mothers at childbirth was $34.23( \pm 6.77)$ years. The most common co-morbid illness was congenital heart disease $(46 \%, 41 / 89)$. The most common chromosomal abnormality was full trisomy $21(95.51 \%, 85 / 89)$.

\section{Conclusion}

Fifty-six percent of children with Down syndrome in this study have thyroid disorders, with subclinical hypothyroidism being the most common. This study provides evidence for the need of regular monitoring of thyroid function test among children with DS.

Published: 28 April 2015

\section{References}

1. Weijerman M, de Winter J P: Clinical practice. The care of children with Down syndrome. Eur J Pediatr 2010, 169:1445-1452.

2. Carroll K, et al: Increase in Incidence of Medically Treated Thyroid Disease in Children With Down Syndrome After Rerelease of American Academy of Pediatrics Health Supervision Guidelines. PEDIATRICS 2008, 122(2): e493-e498.

doi:10.1186/1687-9856-2015-S1-P101

Cite this article as: Matitu-Untalan and Estrada: Prevalence of thyroid disorders among children with Down syndrome seen in the out-patient clinics of the Philippine general hospital. International Journal of Pediatric Endocrinology 2015 2015(Suppl 1):P101.

Philippine General Hospital, Manila, Philippines 